\title{
Prediksi Tingkat Kelancaran Kredit BSU BMT Tunas Harapan Syari'ah Pringgasela Kabupaten Lombok Timur Menggunakan Algoritma Neural Network
}

\author{
Amri Muliawan Nur ${ }^{*}$, Imam Fathurrahman ${ }^{2}$, Yahya $^{3}$ \\ 1,3Program Studi Sistem Informasi, Universitas Hamzanwadi \\ 2Program Studi Teknik Informatika, Universitas Hamzanwadi \\ *muliaamriga@gmail.com
}

\begin{abstract}
Abstrak
Peran kredit dalam suatu koperasi sangat penting. Adanya kredit dapat menjadi sumber keuntungan bagi koperasi. Koperasi didirikan dengan tujuan mensejahterakan anggotanya. Salah satu keuntungannya adalah anggota koperasi dapat mengajukan pinjaman kredit dan untuk menyetujui pinjaman yang diajukan perlu dilakukan analisa terhadap kredit yang diajukan anggota. Hal tersebut menjadi salah satu kesulitan bagi beberapa koperasi salah satunya KSU BMT Tunas Harapan Syari'ah yang terletak di desa Pringgasela Kecamatan Pringgasela Kabupaten Lombok Timur. Permasalahan yang sering muncul adalah analisa yang dilakukan seringkali tidak tepat, sehingga terjadi kredit macet yang berkepanjangan dalam pembayaran angsurannya. Penyebabnya adalah koperasi selalu menggunakan data statistik yang kadang kurang akurat karena tanpa ada proses pengolahan menggunakan metode pengolah data. Oleh karena itu, metode data mining Neural Network dapat digunakan sebagai alat untuk menganalisa nasabah mana yang bermasalah dan tidak bermasalah. Dari hasil penelitian yang telah dilakukan menghasilkan akurasi sebesar $96.19 \%$ dan AUC sebesar 0.976
\end{abstract}

Kata Kunci : Koperasi, Kredit, Algoritma Neural Network, data mining

\begin{abstract}
The role of credit in a cooperative is very important. With the credit can be a source of profit for the cooperative. The cooperative was founded with the aim of prospering its members. One of the advantages is that cooperative members can apply for credit loans. To approve the proposed loan, it is necessary to analyze the credit submitted by the members. This has become one of the difficulties for several cooperatives, one of which is KSU BMT Tunas Harapan Syari'ah which is located in thePringgasela village, Pringgasela District, East Lombok Regency. The problem that often arises is that the analysis conducted is often incorrect, resulting in a prolonged bad credit in installment payments. The reason is that cooperatives always use statistical data which is sometimes inaccurate because there is no processing using data processing methods. Therefore, the neural network data mining method can be used as a tool to analyze which customers are problematic and not problematic. From the results of the research that has been done, it produces an accuracy of $96.19 \%$ and an AUC of 0.976
\end{abstract}

Keywords : Cooperative, Credit, Neural Network Algorithm, data mining 


\section{Pendahuluan}

Koperasi memiliki tujuan untuk mensejahterakan anggotanya sesuai amanat UUD 1945, koperasi memberikan kemudahan kepada anggotanya melalui pemberian kredit, Setiap anggota koperasi memiliki hak yang sama dalam setiap keputusan yang diambil melalui Rapat Anggota Tahunan (RAT). Kredit merupakan penyediaan uang atau tagihan berdasarkan persetujuan atau kesepakatan pinjam meminjam antara koperasi dengan anggotanya, dengan kredit koperasi mewajibkan pihak peminjam melunasi utangnya setelah jangka waktu tertentu dengan pemberian bunga[1].

Koperasi Serba Usaha BMT Tunas Harapan Syari'ah merupakan koperasi kredit yang fokuskan pada usaha simpan pinjam dengan sistem syari'ah yang melakukan kegiatan menghimpun dana dan menyalurakannya kembali kepada anggotanya. Sistem yang digunakan oleh Koperasi Serba Usaha BMT Tunas Harapan Syari'ah adalah dengan prinsip sistem bagi hasil, selain itu terdapat pula prinsip jual beli dengan bunga yang rendah. Pada dasarnya Koperasi Serba Usaha BMT Tunas Harapan Syari'ah menjalankan fungsinya sebagai penyalur kredit, sebagai penyalur kredit sudah barang tentu mempunyai kendala dalam penyaluran kredit yang biasa disebut dengan kredit macet.

Kredit macet merupakan masalah klasik yang selalu dihadapi oleh koperasi kemungkinan terdapat anggota yang bermasalah dalam pembayaran angsurannya. Oleh sebab itu, perlu dilakukan analisa kredit terhadap anggota sebagai calon debitur. Analisa kredit perlu dilakukan guna menghindari resiko keuangan yag disebabkan oleh kredit macet oleh anggota koperasi. Dalam analisa yang dilakukan, perlu dilakukan penilaian kualitatif dan kuantitatif. Penilaian kualitatif adalah penilaian terhadap karakteristik atau sifat dari calon nasabah seperti pekerjaan, status dan lainnya. Sedangkan penilaian kuantitatif adalah penilaian terhadap data calon nasabah yang berbentuk angka dan juga merupakan hasil dari pengukuran dan perhitungan seperti umur, penghasilan, jangka waktu pinjaman, jumlah pinjaman, tunggakan, sisa pokok dan lainnya, penilaian kuantitatif dan kualitatif dalam menganalisa kredit akan memberikan kejelasan bagi pembuat keputusan. Mengingat pentingnya analisa kredit tersebut, dibutuhkan teknik pengolahan data yang baik. Dalam analisa kredit akan dilakukan menggunakan prinsip data mining.

Data mining merupakan aktivitas yang berkaitan dengan pengumpulan data, pemakaian data historis untuk menemukan pengetahuan, informasi, keteraturan, pola atau hubungan dalam data yang berukuran besar yang nantinya akan menghasilkan output yang dapat digunakan sebagai alternatif dalam pengambilan keputusan atau untuk memperbaiki pengambilan keputusan di masa yang akan datang[2]. Data mining 
banyak digunakan di berbagai bidang antara lain retail, pemasaran, manufaktur, keuangan, komunikasi, layanan medis, dan lain-lain. Data mining sendiri merupakan teknik yang digunakan untuk mengolah, mengekstrak (menemukan pola) dan menambang data dari data yang informasinya belum diketahui sebelumnya[3]. Salah satu metode yang sering digunakan dalam data mining adalah algoritma Neural Network. Neural Network merupakan teknik data mining yang paling umum. Teknik ini sangat menarik karena Neural Network menemukan pola dari data secara analogi, sama halnya seperti manusia. Neural Network memiliki kelebihan yaitu keakuratannya yang tinggi dan dapat digunakan pada berbagai jenis masalah. Selain itu Neural Network mampu menyelesaikan masalah-masalah yang sulit dan beragam karena mempunyai kemampuan fault tolerance sampai batas tertentu, sehingga metode ini tetap dapat menghasilkan keluaran meskipun data kurang lengkap. Disamping itu, juga terdapat kelemahannya, model yang dibentuk oleh Neural Network sulit untuk dimengerti, bahkan bagi pakarnya, dan biasanya algoritmanya sensitif dengan format data yang digunakan, kebanyakan output yang diberikan dalam bentuk numerik, sehingga perlu didefinisikan lagi ke value yang actual[4]. Dari uraian di atas penulis akan menerapkan algoritma Neural Network pada KSU BMT Tunas Harapan Syari'ah untuk mendukung prediksi data nasabah mana saja yang akan macet atau lancer dalam pembayaran kreditnya sehingga mengurangi resiko kerugian dalam penyaluran kredit terhadap nasabahnya.

\section{Tinjauan Pustaka \\ 2.1. Penelitian Terkait}

Ada beberapa penelitian yang sudah dilakukan sebelumnya yang terkait dengan penelitian ini antara lain:

\section{"Credit Prediction With Neural Network} Algorithm". Berdasarkan hasil penelitian yang telah dilakukan dengan model algoritma Neural Network untuk mendeteksi kredit macet pada KSP diperoleh nilai akurasi sebesar 96,95\% sehingga sangat baik digunakan untuk memprediksi kredit macet atau lancar. Sedangkan nilai AUC adalah 0,986, artinya hasil dari pengujian ini menunjukkan hasil validasi yang mendekati sempurna[5].

"Perbandingan Performa Metode Klasifikasi SVM, Neural Network, Dan Naïve Bayes Untuk Mendeteksi Kualitas Pengajuan Kredit Di Koperasi Simpan Pinjam". Hasil yang didapatkan adalah metode Neural Network menjadi metode dengan performa paling baik. Rerata tingkat akurasi yang dihasilkan sebesar $86,81 \%$, rerata precision sebesar 0,8194 , rerata recall sebesar 0,8236, dan rerata nilai AUC sebesar 0,9158. Namun, waktu eksekusi yang dihasilkan algoritme Neural Network menjadikan algoritma ini sebagai algoritma paling lambat dibandingkan dengan dua metode lain. Nilai rerata waktu 
eksekusi dari metode Neural Network sebesar 3,058 detik, jauh lebih lama dibandingkan dua algoritme lain yang hanya berkisar pada nilai $0-1$ detik[6].

"Klasifikasi Data Mining Untuk Menentukan Potensi Kredit Macet Pada Koperasi Simpan Pinjam Primkoveri Waleri Menggunakan Algoritma Decision Tree C4.5". Metode yang digunakan dalam klasifikasi adalah metode pengklasifikasian dengan menggunakan desicion tree (pohon keputusan) dengan salah satu algoritma desicion tree yang dipakai adalah C4.5. Hasil dari penelitian dari permasalahan yang dikembangkan dapat disimpulkan bahwa pengimplementasian metode desicion tree terhadap data nasabah kredit Koperasi Primkoveri Waleri tahun 2014 memiliki tingkat akurasi yang baik dalam menyelesaikan solusi klasifikasi data mining dengan algoritma C4.5 yaitu sebesar $86 \%[7]$.

"Penggunaan Algoritma Support Vector Machine (SVM) Untuk Penentuan Kelayakan Pemberian Kredit Koperasi Serba Usaha "Daruzzakah Zakah" Desa Rensing Kecamatan Sakra Lombok Timur Nusa Tenggara Barat”. Dalam penelitian ini menghasilkan nilai akurasi algoritma SVM (Support Vector Machine) dapat dikategorikan sebagai metode yang sangat baik, dengan akurasi $90,42 \%$ dan AUC pada 0,957. Akurasi 90,42\% berarti algoritma SVM dapat memberikan keputusan tentang layak atau tidak layak dalam memberikan kredit kepada pelanggan yang mengajukan pinjaman[8].

\subsection{Landasan Teori}

1. Koperasi

Koperasi berasal dari kata "co" yang berarti bersama dan "operation" berarti bekerja sehingga dapat diartikan sebagai kerjasama. Sedangkan pengertian umum koperasi adalah sekumpulan orang-orang yang mempunyai tujuan yang sama dalam suatu organisasi dengan maksud untuk mensejahterakann anggota yang ada di dalamnya berdasarkan atas asas kekeluargaan. Moh. Hatta selaku "Bapak Koperasi Indonesia" mendefinisikan koperasi adalah usaha bersama untuk memperbaiki nasib penghidupan ekonomi berdasarkan tolongmenolong. Menurut Undang-Undang No. 25 Tahun 1992 menyatakan koperasi adalah badan usaha yang beranggotakan orang seorang atau badan hukum koperasi, dengan melandaskan kegiatannya berdasarkan prinsip koperasi sekaligus sebagai gerakan ekonomi rakyat, yang berdasar atas azas kekeluargaan[9].

\section{BMT (Baitul Maal wa Tamwil)}

Baitul Maal wa Tamwil adalah balai usaha mandiri terpadu yang isinya berintikan bayt almaal wa altamwil dengan kegiatan mengembangkan usaha-usaha produktif dan investasi dalam meningkatkan kualitas kegiatan ekonomi pengusaha kecil bawah dan kecil 
dengan antara lain mendorong kegiatan menabung dan menunjang pembiayaan kegiatan ekonominya.

BMT memiliki dua bidang kerja yaitu sebagai Lembaga Maal(Baitul Maal) dan sebagai lembaga Tamwil (Baitul Tamwil). Baitul Maal yang dimaksud adalah untuk menghimpun zakat dan infak maupun sedekah dan menyalurkan kepada pihak-pihak yang berhak dalam bentuk pemberian tunai maupun pinjaman modal tanpa bagi hasil, yang mana Baitul Maal bersifat nirlaba (sosial). Sedangkan Baitul Tamwil artinya menghimpun dana masyarakat yang mampu dalam bentuk saham, simpanan atau deposito dan menyalurkannya sebagai modal usaha dengan ketentuan bagi hasil antara pemodal dan peminjam dan BMT[10].

\section{Kredit}

Istilah kredit berasal dari bahasa latin "credere" yang berarti kepercayaaan.Kredit diberikan atas dasar kepercayaan. Seseorang atau badan hukum sebagai pemberi kredit (kreditur) percaya bahwa penerima kredit (debitur) dapat mengembalikan pinjaman yang telah diberikan sesuai dengan perjanjian yang telah disepakati. Transaksi kredit timbul karena suatu pihak meminjam sejumlah uang atau sesuatu yang dipersamakan dengan itu, di mana pihak peminjam wajib melunasi kredit atau hutangnya pada waktu yang telah ditentukan[8].
4. Data Mining

Data mining adalah sebuah metode penambangan data yang menemukan pengetahuan dari data yang informasinya masih tersembunyi. Jumlah data yang disimpan oleh suatu organisasi bertambah dengan pesat. Jumlah data meningkat dari tahun ke tahun dan mungkin ada pembayaran dalam mengungkap informasi tersembunyi di balik data yang ada[11]. Data mining atau kadang disebut juga Knowlegde Discovery in Database (KDD) merupakan aktivitas yang berkaitan dengan pengumpulan data, pemakaian data historis untuk menemukan pengetahuan, informasi, keteraturan, pola atau hubungan dalam data yang berukuran besar.

a. Data

Yang harus dipersiapkan pertama kali dalam proses KDD adalah data. Data yang digunakan adalah data yang sudah terpisah dengan data operasional.

b. Selection

Tidak semua data yang ada dapat dipergunakan. Oleh karena itu, dilakukan pemilihan data. Aktivitas pemilihan data meliputi pembuatan kumpulan data target penentuan variabel, pemilihan sampel data dan penyimpanan data pada sebuah berkas.

c. Pre-processing/Cleaning

Pada tahap ini data yang sudah dipilih akan dilakukan pembersihan. Proses cleaning 
meliputi pembuangan duplikasi dataperbaikan data yang inkonsisten, dan perbaikan kesalahan data. Pada prepropresssing/cleaning juga dapat dilakukan proses memperkaya data dengan menambah informasi lain yang relevan yang disebut dengan istilah enrichment.

d. Transformation

Dalam data mining ada begitu banyak algoritma/metode/teknik yang dapat dipergunakan. Hanya sajasetiap algoritma metode teknik tersebut, membutuhkan format data yang berbeda-beda. Oleh karena itu, data yang sudah disiapkan dipergunakan untuk proses $\mathrm{KDD}$, diubah terlebih dahulu sesuai dengan algoritma/metode/teknik yang dipergunakan dalam data mining.

e. Data Mining

Data mining merupakan tahapan utama dalam KDD. Data mining adalah proses penggalian dan pencarian pengetahuan dan informasi yang bermanfaat dengan menggunakan algoritma/metode/teknik tertentu sesuai dengan pengetahuan atau informasi yang dicari.

f. Interpretation/Evaluation

Pengetahuan atau informasi yang dihasilkan dari proses data mining, akan dipresentasikan atau ditampilkan kedalam bentuk yang mudah dimengerti oleh pihak yang berkepentingan seperti informasi ditampilkan dalam bentuk grafik, pohon keputusan ataupun dalam bentuk rule. Pengetahuan atau informasi yang dihasilkan dari proses data mining diperiksa apakah bertentangan atau tidak dengan fakta atau hipotesis yang sebelumnya.

g. Knowlegde

Tujuan utama proses KDD adalah untuk memperoleh pengetahuan atau informasi yang bermanfaat dan mudah dimengerti. Pengetahuan atau informasi yang dihasilkan diimplementasikan sesuai dengan manfaat(kegunaan pengetahuan atau informasi tersebut.

\section{Algoritma Neural Network}

Neural Network adalah suatu metode komputasi yang meniru sistem jaringan saraf biologis. Metode ini menggunakan elemen perhitungan non-linier dasar yang disebut neuron yang diorganisasikan sebagai jaringan yang saling berhubungan, sehingga mirip dengan jaringan saraf manusia. Layaknya neuron biologi, Jaringan saraf tiruan juga merupakan sistem yang bersifat "fault tolerant" dalam 2 hal[12].

\section{RapidMiner}

RapidMiner merupakan perangkat lunak open source untuk data mining dan machine learning, perangkat lunak ini dibuat oleh Dr. Markus Hofman, Mr. Ralf Klinkenberg dan Ms. Geraldine Gray dari Institut of Technology Blanchrdstown. Perangakat ini digunakan untuk training model 
dan menguji keakuratan model yang telah terbentuk, bahasa pemrograman yang digunakan adalah bahasa Java, dengan lisensi dari GNU Public License. Hasilnya dapat segera diketahui bagaimana model yang terbentuk dan sekaligus hasil pengujian untuk akurasi model yang dihasilkan[5].

\section{Dataset}

Dataset adalah suatu database di dalam memori (in-memory) yang terdiri dari tabel-tabel yang saling terkait (relationship) dengan foreign key dan integritas referensial. Dataset memiliki semua karateristik, fitur dan fungsi dari database biasa. Dataset adalah objek yang mempresentasikan data dan relasinya di memori. Strukturnya mirip dengan data yang ada di database. Dataset berisi koleksi dari tabel dan data[8].

\subsection{Tahapan Penelitian}

Pada gambar 1 tahapan dari penelitian ini meliputi beberapa tahapan diantaranya:

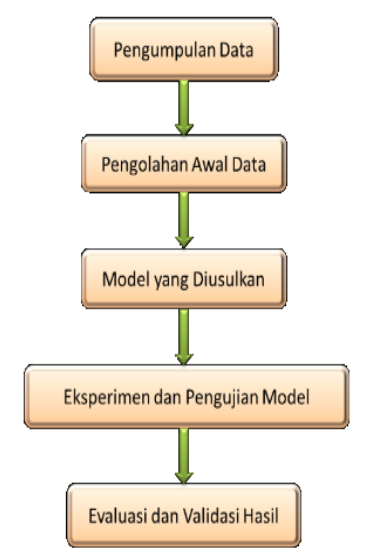

Gambar 1. Tahapan Penelitian
1. Pengumpulan Data

Dalam pengumpulan data primer berupa data kredit nasabah, peneliti memperoleh langsung dari objek penelitian yaitu KSU BMT Tunas Harapan Syari'ah Pringgasela. Sedangkan data sekunder diperoleh melalui buku, jurnal dan lain-lain yang berkaitan dengan pembiayaan/kredit pada koperasi.

2. Pengolahan Data

Data yang telah diperoleh harus diolah terlebuh dahulu dengan melakukan penyeleksian data, data dimodifikasi sesuai kebutuhan dan ditransformasikan kedalam bentuk yang diinginkan sehingga dapat dilakukan persiapan dalam pembuatan model.

3. Model Yang Diusulkan

Pada tahap ini data dianalisis, dikelompokan variabel mana yang berhubungan dengan satu sama lainnya.Setelah data dianalisis lalu diterapkan model-model yang sesuai dengan jenis data. Pembagian data kedalam data latihan (training data) dan data uji (testing data) juga diperlukan untuk pembuatan model. Dalam penelitian ini menggunakan model algoritma Neural Network.

4. Eksperimen dan Pengujian Model

Ekperimen yang dilakukan pada penelitian ini menggunakan Neural Network. Pemodelan dilakukan dengan menggunakan Software Rapidminer yang 
merupakan salah satu software pemodelan terbaik saat ini yang menyediakan lingkungan kerja yang bagus untuk tugas data mining.

5. Evaluasi dan validasi hasil

Dilakukan evaluasi terhadap model algoritma Neural Network untuk mengetahui tingkat keakurasian, kualitas dan efektivitas model. Accuracy akan dihitung dari seluruh data yang benar dibagi dengan data keseluruhan. Semakin tinggi nilai accuracy, semakin baik pula model yang dihasilkan[[13], [14]].

Proses evaluasi menggunakan metode ROC (Receiver Operating Characteristic) (Fawcett, 2005). untuk mencari nilai AUC (Area Under the ROC Curve) tertinggi dengan software Rapidminer. AUC merupakan teknik untuk memvisualisasikan, mengatur dan memilih pengklasifikasian berdasarkan kinerja model (Akthar \& Hahne, 2012).

\section{Metode Penelitian}

Metodologi yang digunakan dalam penelitian ini antara lain sebagai berikut :

1. Business understanding Tahapan ini merupakan tahapan awal penelitian dengan menganalisis factor factor yang mempengaruhi tingkat kredit macet dan lancar pada kredit KSU BMT Tunas Harapan
Syari'ah Pringgasela dari tahun 2017 s/d Juni 2020.

2. Data Understanding

Terdapat 128 data nasabah dengan 15 atribut yang terdiri dari 41 nasabah dengan status Lancar, 3 Kurang Lancar dan 84 nasabah dengan status Macet. Atribut atau variabel yang ada diantaranya Nomor Rekening, Tanggal Realisasi, Jangka Waktu, Jatuh Tempo dan lainnya.

3. Data Preparation

Pada tahap ini akan dilakukan beberapa penyeleksian untuk menghasilkan data yang dibutuhkan, tahapannya yaitu:

a. Data Cleaning untuk membersihkan nilai kosong atau tupel yang kosong.

b. Data integration berfungsi menyatukan tempat penyimpanan (arsip) yang berbeda kedalam satu data. Dalam hal ini hanya ada satu tempat penyimpanan data namun dipisahkan berdasarkan bulan, maka dengan tahap ini semua data perbulan akan disatukan.

c. Data reduction, beberapa atribut yang tidak digunakan akan dihapus sehingga tersisa atribut yang berpengaruh saja berjumlah 9 atribut. Selain itu menghapus duplikasi tupel-tupel yang ada dengan nilai yang sama akan dijadikan dalam satu tupel untuk mewakili tupel tersebut. Sehingga data 
yang semula 128 berkurang menjadi 108 record

Sehingga data yang akan di gunakan pada penelitian ini berjumlah 108 record dengan 9 atribut.

\section{Modelling}

Tahap ini dapat disebut juga tahap learning karena pada tahap ini data training diklasifikasikan oleh model, kemudian menghasilkan sejumlah aturan. Model yang digunakan pada tahap ini menggunakan model algoritma Neural Network.

\section{Hasil dan Pembahasan}

\subsection{Hasil Pengolahan Data}

Pengujian ini dilakukan untuk mengetahui kinerja dari metode algoritma Neural Network dalam melakukan prediksi terhadap kelas yang telah ditentukan.

Dari 9 kali pengujian dapat ditampilkan 2 kali sampel pengujian yang merupakan sampel dengan nilai akurasi terbaik yaitu K-Fold Validation 4 dan K-Fold Validation 7.

a. Pengujian 1 (K-Fold Validation4)

Pada Table. 1 Merupakan hasil uji coba yang dilakukan yaitu untuk menghasilkan nilai accuracy, hasil akurasi yang diujikan adalah $95,37 \%$.
Tabel 1. Hasil Accuracy dengan K-Fold Validation 4

\begin{tabular}{ccc}
\hline Observed Class & Macet & Lancar \\
\hline Macet & 73 & 4 \\
\hline Lancar & 1 & 30
\end{tabular}

Jumlah true positif (TP) adalah 73 record diprediksikan MACET membayar kredit dan false negatif (FN) sebanyak 1 record diprediksikan MACET namun LANCAR dalam membayar kredit. Berikutnya 30 record untuk true negatif (TN) diprediksikan untuk LANCAR membayar kredit, dan 4 record false positif (FP) diprediksikan LANCAR namun ternyata MACET dalam membayar kredit.

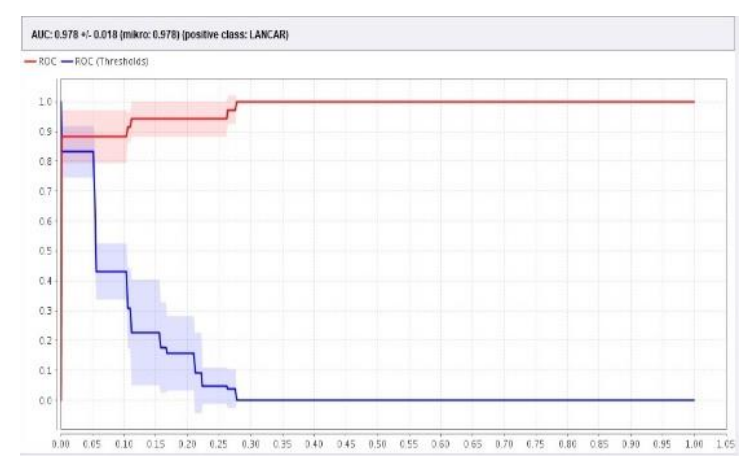

Gambar 2. Nilai AUC dalamGrafik ROC dengan K-Vod Validation 4

Gambar 2 menunjukan nilai AUC (Area Under Curve) dengan hasil Accuracy dengan K-Fold Validation 4 sebesar $0.978 \%$ dengan nilai akurasi Excellent Classification.

b. Pengujian 2 (K-Fold Validation7)

Table 2. Merupakan hasil uji coba yang dilakukan yaitu untuk menghasilkan nilai accuracy, hasil akurasi yang diujikan adalah 
$96,19 \%$.

Tabel 2. Hasil Accuracy dengan K-Fold Validation 7

\begin{tabular}{ccc}
\hline Observed Class & Macet & Lancar \\
\hline Macet & 74 & 4 \\
\hline Lancar & 0 & 30
\end{tabular}

Jumlah true positif (TP) adalah 74 record diprediksikan MACET menerima kredit dan tidak ada record di false negatif (FN) yang diprediksikan MACET namun LANCAR dalam membayar kredit. Berikutnya 30 record untuk true negatif (TN) diprediksikan sebagai LANCAR membayar kredit, dan 4 record false positif (FP) diprediksikan LANCAR namun ternyata MACET.

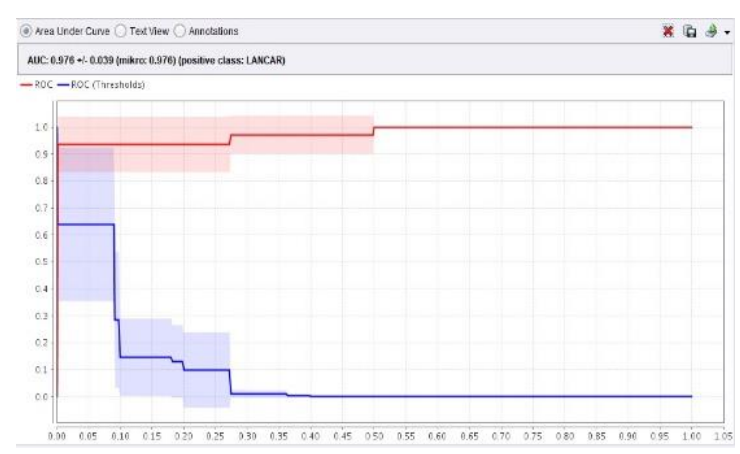

Gambar 3. Nilai AUC dalamGrafik ROC dengan K-Vod Validation 7

Apat dilhat pada gambar 3 Memiliki nilai AUC (Area Under Curve) dengan hasil Accuracy dengan K-Fold Validation 7 sebesar $0.976 \%$ dengan nilai akurasi Excellent Classification.

\subsection{Pembahasan}

Tujuan dari penelitian ini adalah untuk menguji keakuratan analisa prediksi tingkat kelancaran dan kemacetan kredit dengan menggunakan
Algoritma Neural Network. Dari uji coba menggunakan $k$-fold validation 2 sampai $K$-Fold Validation 10, ditemukan nilai Accuracy, Ppv, Npv, Sensitivity, Specificity, AUC.

Hasil uji coba terbaik adalah pada K-Fold Validation 4 sebesar $95.37 \%$ dan K-Fold Validation 7 sebesar $96.19 \%$, dan selisih akurasi di antara keduanya adalah $0.82 \%$ seperti yang terlihat pada Tabel 3 dibawah.

Tabel 3. Hasil Uji Coba K-Fold Validation 2

Sampai 10

\begin{tabular}{|c|c|c|c|c|c|c|}
\hline \multirow{2}{*}{$\begin{array}{c}\text { valid } \\
\text { ation }\end{array}$} & $\begin{array}{c}\text { Uccura } \\
\text { cy }\end{array}$ & Ppv & Npv & $\begin{array}{c}\text { Sens } \\
\text { itivity }\end{array}$ & $\begin{array}{c}\text { Spec } \\
\text { ificity }\end{array}$ & AUC \\
\hline 2 & $92,59 \%$ & $91,25 \%$ & $96,43 \%$ & $\begin{array}{c}98,65 \\
\%\end{array}$ & $\begin{array}{c}79,41 \\
\%\end{array}$ & 0.926 \\
\hline 3 & $94,44 \%$ & $92,50 \%$ & $100 \%$ & $100 \%$ & $\begin{array}{c}82,35 \\
\%\end{array}$ & 0.970 \\
\hline 4 & $95,37 \%$ & $94,81 \%$ & $96,77 \%$ & $\begin{array}{c}98,65 \\
\%\end{array}$ & $\begin{array}{c}88,24 \\
\%\end{array}$ & 0.978 \\
\hline 5 & $90,82 \%$ & $90,00 \%$ & $92,86 \%$ & $\begin{array}{c}97,30 \\
\%\end{array}$ & $\begin{array}{c}76,47 \\
\%\end{array}$ & 0.954 \\
\hline 6 & $91,67 \%$ & $92,21 \%$ & $90,32 \%$ & $\begin{array}{c}95,95 \\
\%\end{array}$ & $\begin{array}{c}82,35 \\
\%\end{array}$ & 0.948 \\
\hline 7 & $96,19 \%$ & $94,87 \%$ & $100 \%$ & $\begin{array}{c}100 \% \\
\%\end{array}$ & $\begin{array}{c}88,24 \\
\%\end{array}$ & 0.976 \\
\hline 8 & $92,65 \%$ & $94,59 \%$ & $88,24 \%$ & $\begin{array}{c}94,59 \\
\%\end{array}$ & $\begin{array}{c}88,24 \\
\%\end{array}$ & 0.966 \\
\hline 9 & $94,44 \%$ & $94,74 \%$ & $93,75 \%$ & $\begin{array}{c}97,30 \\
\%\end{array}$ & $\begin{array}{c}88,24 \\
\%\end{array}$ & 0.961 \\
\hline 10 & $92,55 \%$ & $92,31 \%$ & $93,33 \%$ & $\begin{array}{c}97,30 \\
\%\end{array}$ & $\begin{array}{c}82,35 \\
\%\end{array}$ & 0.960 \\
\hline
\end{tabular}

Dapat disimpulkan bahwa nilai dengan hasil terbaik yaitu terdapat pada K-Fold Validation 7 dengan nilai accuracy sebesar $96.19 \%, P p v$ sebesar $94,87 \%$, Npv sebesar $100 \%$, Sensitivity sebesar $100 \%$, Specificity sebesar $88,24 \%$ dan nilai Area Under Curve (AUC) adalah 0.976 dengan predikat Excellent Classification (klasifikasi yang sangat baik). 


\section{Kesimpulan}

Dari hasil penelitian yang telah dilakukan, maka dapat disimpulkan bahwa metode ini mampu menganalisa kredit yang bermasalah dan tidak bermasalah, dimana dilakukan dengan cara melakukan perhitungan sesuai dengan kinerja algoritma Neural Network untuk menghasilkan model sehingga masuk dalam kategori excellent classification, dengan pembuktian hasil akurasi diperoleh sebesar $96.19 \%$ dan AUC sebesar 0.976. Dari dua kali percobaan dapat diketahui bahwa keberhasilan Neural Network sangat dipengaruhi oleh kualitas data dan pemilihan atribut yang tepat. Semakin data bervariasi maka akan menghasilkan akurasi yang tinggi dan semakin banyak atribut dan informasi yang tidak berpengaruh digunakan, dapat mengurangi tingkat akurasi yang lebih tinggi.

\section{Daftar Pustaka:}

[1] A. Setiadi, "Penerapan Algoritma Radial Basis Functions untuk Prediksi Kelayakan Pemberian Kredit," Konf. Nas. IImu Sos. Teknol., pp. 607-612, 2017.

[2] E. Buulolo, Data Mining Untuk Perguruan Tinggi, I. Yogyakarta: DEEPUBLISH, 2020.

[3] A. M. Nur, M. F. Wazdi, B. Harianto, and M. F. Zaini, "Implementation of Naive Bayes Algorithm in Analyzing Acceptance of Poor Student Assistance," Journal of Physics: Conference Series, vol. 1539, no. 1. IOP Publishing, p. 12018, 2020.

[4] N. Iriadi, "Komparasi Algoritma Klasifikasi Data Mining Dalam Penentuan Resiko Kredit Pada Koperasi Serba Usaha," Paradigma, vol. XV, no. 2, pp. 192-204,
2013.

[5] I. A. Sucipto, "CREDIT PREDICTION WITH NEURAL NETWORK ALGORITHM," no. 15, pp. 978-979.

[6] I. T. A. Nur, N. Y. Setiawan, and F. A. Bachtiar, "Perbandingan Performa Metode Klasifikasi Svm, Neural Network, Dan Naïve Bayes Untuk Mendeteksi Kualitas Pengajuan Kredit Di Koperasi Simpan Pinjam," J. Teknol. Inf. dan IImu Komput., vol. 6, no. 4, pp. 445-450, 2019, doi: 10.25126/jtiik.201961352.

[7] A. R. Wicaksono and Y. Rahayu, "Klasifikasi Data Mining Untuk Menentukan Potensi Primkoveri Waleri Menggunakan Algoritma Decision Tree C4.5," 2014.

[8] Yahya and M. H. Nasution, "Penggunaan Algoritma Support Vector Machine (SVM) Untuk Penentuan Kelayakan Pemberian Kredit Koperasi Serba Usaha 'Daruzzakah Zakah' Desa Rensing Kecamatan Sakra Lombok Timur Nusa Tenggara Barat," J. Inform. dan Teknol., vol. 3, no. 1, pp. 32-41, 2020.

[9] Syamsiah, "Pemilihan Model Penentuan Kelayakan Pinjaman Anggota Koperasi Berdasarkan Algoritma Support Vector Machine , Genetic Algorithms, Dan Neural Network," Fakt. Exacta, vol. 7, no. 2, pp. 141-153, 2014.

[10] S. M. C. Wahyuono, "Pertanggungjawaban Hukum Penyelesaian Pembiayaan Tak Tertagih Di BMT-PSU Malang," Malang, 2019.

[11] A. M. Nur and B. Harianto, "Komparasi Algoritma SVM Dan SVM Berbasis PSO Dalam Menganalisis Kinerja Guru SMAN 3 Selong," Infotek J. Inform. dan Teknol., vol. 2, no. 2, pp. 86-94, 2019.

[12] A. P. Windarto, M. R. Lubis, and Solikhun, "Model Arsitektur Neural Network Dengan Backpropogation Pada Prediksi Total Laba Rugi Komprehensif Bank Umum Konvensional," Kumpul. J. IImu Komput., vol. 05, no. 02, pp. 147158, 2018. 
Infotek : Jurnal Informatika dan Teknologi

Vol. 4 No. 2, Juli 2021

Hal. 205-216

e-ISSN 2614-8773

DOI : 10.29408/jit.v4i2.3580 Link : https://dx.doi.org/10.29408/jit.v4i2.3580

[13] I. Fathurrahman, A. Muliawan Nur, and F. Fathurrahman, "Identifikasi Kematangan Buah Mentimun Berbasis Citra Digital Menggunakan Jaringan Syaraf Tiruan Backpropagation," Infotek J. Inform. dan Teknol., vol. 2, no. 1, pp. 27-33, 2019, doi: $10.29408 / j i t . v 2 i 1.976$.

[14] I. Fathurrahman and I. Gunawan, "Pengenalan Citra Logo Kendaraan Menggunakan Metode Gray Level Co-
Occurence Matrix (Glcm) dan JstBackpropagation," Infotek J. Inform. dan Teknol., vol. 1, no. 1, pp. 47-55, Jan. 2018, doi: 10.29408/jit.v1i1.894.

[15] A. Sudianto and J. Sugiantara, "Website as Foundation Information Media under the auspices of Nahdlatul Wathan," $J$. Phys. Conf. Ser., vol. 1539, no. 1, pp. 3$8, \quad 2020$, doi: 10.1088/17426596/1539/1/012024 